\title{
Higher education between massification and quality
}

\author{
Rabah Noui \\ Social sciences, University of Bejaia, Bejaia, Algeria
}

\begin{abstract}
Purpose - The purpose of this paper is to examine how the policy of massification as a characteristic of the higher education system influences the quality of education? and what higher education model can the authors adopt to reconcile flow and quality?

Design/methodology/approach - The methodology adopted is based on a questionnaire survey of a population of young graduates divided between graduates with a conventional license and LMD license, either in the process of preparing for a diploma or in unemployment or work. But also, the qualitative dimension which, although secondary in this survey, the authors mobilized it through the analysis of open questions relating to the perceptions and representations that young graduates have of their situations.

Findings - The higher education reforms are perceived differently by higher education actors. The results found show that university massification has had the opposite effect by training graduates doomed to unemployment and expatriation.

Research limitations/implications - The sample for this study is very limited, the results of this finding cannot be generalized to the entire university student as a whole.

Originality/value - This study emphasizes the duality of flow and quality in higher education. The authors have shown the different perceptions of stakeholders in higher education and that despite the multiple reforms of this system the authors still cannot find the best model.
\end{abstract}

Keywords Social science students, Higher education, Reforms, Massification, Quality, Flow, Employability

Paper type Research paper

\section{Introduction}

In recent decades, the higher education sector has become a focus of attention in several developed and developing countries. It is facing multiple challenges and is affected by major changes at several levels.

The strategic importance of the higher education sector is regularly highlighted by the reports of various international bodies (UNESCO, OECD, World Bank (WB)) which agree that the higher education sector must respond to the new needs of the socioeconomic world by training workers capable of integrating into the local and international labor market. In addition, the challenges surrounding higher education are becoming more and more accentuated, in particular with the phenomenon of massification observed in recent years resulting inter alia from the democratization of access to universities and the demographic surge. Massive access to higher education affects both developed and underdeveloped countries with a certain chronological difference. It is one of the major features of the 20th and 21st century (Guri-Rosenblit et al., 2007). The total number of the student population increased from 146 million in 2006 to more than 218 million students in 2016 (Migaud et al., 2019) and it should reach according to the latest estimates 243 million in 2020 and more than 265 in 2025 . These figures clearly show the rise in access higher education and the place it occupies in national and government policies. All governments strive, through an efficient

(C) Rabah Noui. Published in Higher Education Evaluation and Development. Published by Emerald Publishing Limited. This article is published under the Creative Commons Attribution (CC BY 4.0) licence. Anyone may reproduce, distribute, translate and create derivative works of this article (for both commercial and non-commercial purposes), subject to full attribution to the original publication and authors. The full terms of this licence may be seen at http://creativecommons.org/licences/by/4.0/ legalcode

Received 23 April 2020 Revised 4 August 2020 Accepted 24 October 2020

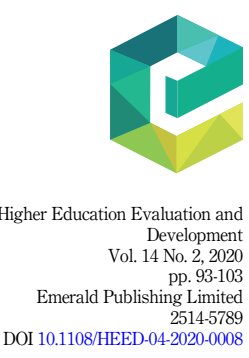


HEED

14,2

94

higher education system, to train highly skilled and high value-added workers. To this end, the new development approaches regard knowledge as a key factor for achieving sustainable economic development. To meet the requirements of accountability imposed by the local and international socioeconomic environment, higher education has adopted a quality approach which is part of the new structural reforms aimed at promoting university education. However, the massification and quantitative expansion of the higher education sector makes the demand for quality an insurmountable challenge by producing the opposite of what it claims to do. Through the famous License, Master and Doctorate (LMD) system reform initiated by the Bologna Process [1], we try to analyze the relationship between the quality of university education and the management of student flows in light of the main foundations of $\mathrm{LMD}[2]$.

\section{Higher education in the Arab world: models and directions}

The state and performance of higher education systems differ significantly from one region to another. Like all countries of the world, higher education in the Arab region is crossed by great historical, religious and political movements which shape its mode of operation and influence its orientations. Despite the geographic proximity, cultural and historical rapprochement of the Arab countries, the latter adopt very diverse higher education models according to the strategic objectives and missions assigned to the sector. Over the past two decades, the majority of Arab countries have been under pressure from major neoliberal international bodies, such as the WB and the International Monetary Fund (IMF), which have imposed structural adjustment policies on these countries by ushering in a new era of corporate privatization and by significantly reducing spending in the higher education sector except the primary and secondary cycles. Major transformations have taken place following the various adjustment plans.

The new higher education sector reforms adopted under the leadership of international institutions aim now at rehabilitating the sector to the new challenges dictated by a situation of privatization and the search for new skills. Higher education reform in the region confronted with a myriad of challenges that spread over demographic, political and economic considerations, and these are unlikely to overcome in the next 10-20 years' time (see for example Wilkens, 2011). States in this region with the largest number of enrollments are Egypt (2.8 million in 2016), followed by Saudi Arabia (1.6 million) and Algeria (1.4 million). Out of the 20 states included in this region, there are timely data for 14 and for the remaining six data lags four or more years (Calderon, 2018).

To this end, we can classify the different models adopted in the context of these reforms as follows:

The liberal model: The corporatization and marketisation of the universities has its origins in neo-liberal politics that is premised on the assumption that the market can replace the democratic state as the primary producer of cultural logic and value (Lynch, 2006). The neoliberalism has contributed to a market-based approach to the management of educational institutions, valuing the economic liberty central to privatizing education (Winston, 2016).

In spite of multiple and sharp criticisms against the neoliberalist reforms known as a marketization of knowledge, this model knows a peak without precedent in certain countries of the Arab world. It involves expanding access to higher education while offsetting costs for consumers and the private sector. This includes the creation of private universities and programs such as "Open Learning" and "Parallel Learning" whereby students pay small fees to study programs that they could not have taken only with their degrees (Buckner, 2019). Several countries in particular in the Middle East have been adopting this model for several years such as Jordan, Palestine, Syria and Egypt. However, the privatization phenomenon 
induced by the neoliberal system could not have produced the desired effects of economic integration, which is explained in some cases by the observed discrepancy between the economic machine and training.

The turnkey relocation model: although it pursues orientations similar to that of the neoliberal system, this model consists in relocating a prestigious international campus to a foreign country by using its brand image and reputation and by importing programs and diplomas. This is mainly an Americanization of higher education where the desire to "modernize" higher education systems has not only taken the form of an extensive privatization of the supply of higher education, as many Neoliberal states but also establishing broad international partnerships with American and British universities (Buckner, 2019).

The establishment of American and British universities mainly characterizes the Arab Gulf States such as Qatar and Dubai, which instead of focusing on improving the quality of teaching and the transfer of knowledge, they invited the major universities to settle in the country. The strategic objectives of this relocation seem to go beyond preparing graduates for the demands of the job market (less than $10 \%$ of the local population benefits from access to these universities) but rather using the reputation and prestige of these campuses to build a brand image and buy some legitimacy!

The quality assurance model: Unlike previous models, the quality assurance model is largely based on the role of the state in the regulation and governance of the higher education sector. It must ensure compliance with the quality of training and reinforce sector efficiency and performance.

As a system, quality assurance is a permanent and continuous process to assess (assess, control, guarantee, maintain and improve) the quality of the higher education provided. Establishing a culture of quality requires rigorous and determined management on the part of local and global higher education officials. The quality assurance model is widely adopted in the Maghreb countries (Algeria, Morocco, Tunisia) because it allows these states to exercise control over the sector and adjust it according to new challenges that operate around the world.

The quality assurance model seems hybrid and has its origins in the work of the European Union initiated by the declaration of the Sorbonne in 1998 and a year later by the construction of the Bologna Process. The latter inaugurates a novelty in higher education policies which are now based on a new principle, that of the knowledge economy. This is how we are witnessing a new definition of "human capital" "no longer in reference to a qualification acquired and protected by sectoral collective agreements but on the individual capacity to cultivate one's "employability" and permanent maintenance of his skills" (Hely and Oeser, 2015).

It goes without saying that this third model mainly aims to match university education to the demands of the job market. The governments of the Maghreb countries have recently sought large-scale quality assurance programs inspired by the Bologna Process by restructuring the conditions for the degree to be awarded under the License-Masters- $\mathrm{PhD}$ system. This approach attempts to align higher education programs with models and allow international mobility of qualifications. The various conventions ratified within the framework of international mobility programs (Erasmus mundus, Averroes, Tassili, Profas ...) are immediately part of this logic of modernization, quality and upgrading of education players superior.

It is not surprising that these forms occur in North African countries that rely on external migration to Europe; however, the success and quality improvement of these programs is not yet clear (Ferroukhi, 2009).

It remains to be mentioned that the adoption of a particular higher education model does not prevent the adoption of certain principles from the other models.

Massification and quality 
HEED

14,2

96

Higher education in Algeria: from the national university to the Bologna Process

In Algeria, the higher education system has undergone profound transformations and multiple reforms which go hand in hand with its mission. Historically, this sector trained elites for the building of countries as well as to replace the French skills that left the country. To these reconstruction tasks are added "political functions of social control and legitimization of the powers in place (Khelfaoui, 2003)".

Influenced by a historical and geopolitical context, the Algerian university went through several phases each of them is characterized by dominant features, in the aftermath of independence until 1971, higher education was limited to a very limited category of the Algerian population (elitist) characterized mainly by political instrumentalization under the qualifier of the national university (Ghouati, 2012). From 1971, the economic dimension took over, a first overhaul of higher education was introduced aimed at professionalizing training offers to meet the needs of public enterprises in terms of skilled workers but also liberalize the university and get off the colonial beaten track. However, these reforms were not completed, abandoned because of the political conflicts and popular uprising of October 1988 followed by the dark decade (terrorism). The considerable drop in the quality of training, added to the economic crisis, will result in massive unemployment of higher education graduates already reaching several tens of thousands in 1990 (Ali-Rachedi and Abdesselam, 2006).

From the 2000s, the institution changed its morphology, recruited more teachers and opened even more teaching and research structures, but its student enrollment increased much faster than the reception structures: they were doubled in September 1999-2000 (with more than 400,000 students) (Ghouati, 2012).

However, from the 2000s, a new trend in the internationalization of the higher education system emerged, motivated by a context of economic globalization and transition to a market economy. Without doubt, one of the flagships and consequent reforms of the higher education sector is the adoption of the LMD. The term reform or LMD system - adopted with the mediation of France means a set of objectives aimed at transforming higher education within the framework of the Bologna Process. That is to say, a harmonization of the architecture of training offers according to three types of diplomas (License, Master and Doctorate) corresponding to three exit levels in three, five and eight years, respectively (Ghouati, 2012).

From 2003, these reforms were extended to all Maghreb countries (Algeria, Morocco, Tunisia). The European and North African leaders have officially praised the process, although the students and the teachers did not support its institutional aims (Ghouati, 2012).

This process has, on the one hand, encouraged $\mathrm{HE}$ institutions to reinforce their activities outside the domestic market, in terms of international mobility of students and faculty members, or training and/or research programs. On the other hand, it has encouraged them to incorporate locally the international (Hatimi, 2018). It aims to standardize and internationalize the higher education system in the sense that internationalization means a series of international activities such as academic mobility for students and teachers; international linkages, partnerships and projects; new international academic programs and research initiatives (Knight, 2008).

These events raise the question whether an integration of the criteria for reforms resulting from the BP means "modernization", that is to say an improvement in the quality of training, research and the governance of education systems. higher education and the adaptation of graduates to the needs of the economy and society (Ghouati, 2012).

\section{A mass-oriented higher education system}

The higher education system has gone through several mass movements, the first wave seen in the 1960s and 1970s in North America and the Pacific mainly due to population growth and 
the democratization of higher education. A second wave of massification has started since the late 1980s and 1990s in Europe and gradually in the Arab world. The latter exploded student numbers from the 2000s, particularly in Egypt and Algeria with more than three million students and no less than two million, respectively.

The term "massification" denote mass enrollments in a national system and the term was first used by Martin Trow.

A "mass system" is one in which the prevailing attitude is that access to higher education is a right for those with certain qualifications. The function of higher education in a "mass system" is the transmission of skills and the preparation of the population for broader range of technical and economic elite roles (Trow, 2006).

The massification of higher education and the over-issuance of diplomas on the one hand, and the stagnation of the job market on the other, have led to the massive downgrading of academics as well as unemployment of graduates. But as paradoxical as it may be, this situation does not dissuade students from pursuing higher education.

In addition, the massification of higher education has changed the university landscape as well as the enrollment profile characterized by increasing feminization and diverse social and geographic origins. New trends in the higher education sector appeared to mitigate the effects of massification, it is primarily a question of moving toward the creation of universities and private providers. The Algerian state does not seem to appreciate this approach to privatization despite the promulgation of a law published in the Official Journal in 2008 (Official Journal, 2008). The diversification of training offers, the orientation of students toward professional branches, international mobility, cooperation project are all measures taken to counter the consequences of massification.

The policy of massification of higher education in the Arab world combined with unemployment of graduates pushes students to modify their objectives and expectations with regard to higher education targeting scientific immigration and expatriation.

\section{New role in the higher education sector and decoupling industry-university}

The university plays a key role at several levels, not only scientific but also and above all political and social ones. As a result, recent changes at the university have gone hand in hand with the changes taking place around the world. This strategic place has made of the university a field of intervention for several actors and stakeholders: scientists, experts, politicians, entrepreneurs.

It goes without saying that the higher education system and the pedagogical and academic model are deeply affected, even shaped by the ideological, political and economic transformations that characterize the new world order. The expression "university globalization" which designates at the same time the intensification of exchanges between universities in different countries, the increase in international mobility and the connection of transformations to the universal extension of a liberal economic mode of opening up markets and privatization (Leclerc-Olive et al., 2011)»

This increasing complexity of the university environment therefore implies that the university should not only be seen as a higher education institution and a simple knowledge transmission agent but also as an institutional springboard toward employment and economic growth. As a result, improving the employability and professional integration of graduates is a major challenge for the Algerian university. In this perspective, the Ministry of Higher Education and Scientific Research has carried out an evaluation of the LMD system by engaging in a broad debate with the university family, in particular teachers and students, through the provision of the university community, a website which enriches the work of the national LMD system evaluation conference.

Massification and quality 
HEED

14,2

\section{Methods and materials}

The nature of the subject treated and its understanding from a multidisciplinary angle (psychosociological and economic) imply that we are interested in both the quantitative and qualitative data. The quantitative dimension is reflected through a statistical reading of various documents and statistical reports as well as an empirical exploration by the distribution of a questionnaire to the surveyed population. Concerning the qualitative dimension, it consists of the analysis of open questions related to the perceptions and representations that young graduates have of their situations. The methodology adopted is based on a questionnaire survey of a population of young graduates divided into groups of graduates with a conventional license and LMD license, either in the process of preparing for a diploma or in unemployment or work. We distributed 120 questionnaires and collected 76 which indicates a high nonresponse rate of $37 \%$. Due to confinement imposed by the health situation in the world, the questionnaire was administered electronically, using the free Google form platform, by distributing the link of the survey via social networks, where we have eliminated questionnaires from respondents who do not meet certain basic conditions such as those who did not go to university! The latter comprising a set of closed and open questions that revolve around four main axes: first; the axis reserved for the personal data of the respondents (which serves, among other things, to identify the profile of the respondents), then the university training axis (LMD, classic [3], specialty), the third axis is dedicated to the professional life of the respondents (professional orientations, relationship between diploma and the world of work.) Finally, the last axis is reserved for the collection of perceptions and representations that graduates have of their diplomas and of the productive world within the framework of a highly massed education.

\section{Results and discussion}

Through this part, we will expose the different results and data collected during our empirical investigation. It is mainly dedicated to the presentation of the personal data of the respondents as well as to the perceptions and attitudes that they develop with regard to the multiple reforms and the new transformation of higher and higher education.

\section{Socioeconomic profile of respondents}

At the end of our empirical investigation we constructed statistical tables and analyzed the results which contain, among other things, the characteristics of the socio-professional data of the population studied in order to know the qualities that characterize the respondents and to understand the structure as well as the context in which the investigation took place.

The above results show the distribution of respondents by sex, age and professional activity. As a result, we find that the male sex is slightly higher with 41 respondents, or $53.9 \%$ of the population studied. Whereas, the female sex constitutes $46.1 \%$, that is to say the number of 35 respondents of all the respondents. As for the age of our respondents, it is characterized by a variety of age groups which reflects the initial structure of the mother population (students and graduates). Of course, we have adopted these age groups according to the preparation period of each diploma.

In terms of professional activity, our survey population is very diverse. As a result, given the nature of the subject covered, more than $51 \%$ of those questioned are students, followed by the category of civil servants (graduates from higher education) with $30.3 \%$, then the unemployed (graduates). This distribution of respondents into categories (students at the start of the course, at the end of the course, graduate, unemployed graduates, worker graduates) will allow us to understand the perceptions of each category to see the difference induced by the socioeconomic conditions of each group (see Table 1). 


\begin{tabular}{|c|c|c|c|c|c|}
\hline & Headcounts & Percentage & Valid percentage & Cumulative percentage & Massification \\
\hline \multicolumn{6}{|l|}{ Gender } \\
\hline Male & 41 & 53.9 & 53.9 & 53.9 & \\
\hline Female & 35 & 46.1 & 46.1 & 100.0 & \\
\hline Total & 76 & 100.0 & 100.0 & & \\
\hline \multicolumn{4}{|l|}{ Age (year) } & & 99 \\
\hline $18-21$ & 8 & 10.5 & 10.5 & 10.5 & \\
\hline $22-25$ & 15 & 19.7 & 19.7 & 30.3 & \\
\hline $26-30$ & 23 & 30.3 & 30.3 & 60.5 & \\
\hline More than 30 & 30 & 39.5 & 39.5 & 100.0 & \\
\hline Total & 76 & 100.0 & 100.0 & & \\
\hline \multicolumn{6}{|l|}{ Professional activity } \\
\hline Student & 39 & 51.3 & 51.3 & 51.3 & \\
\hline Merchant & 1 & 1.3 & 1.3 & 52.6 & \\
\hline Company director & 1 & 1.3 & 1.3 & 53.9 & \\
\hline Official & 23 & 30.3 & 30.3 & 84.2 & \\
\hline Unemployed & 12 & 15.8 & 15.8 & 100.0 & \\
\hline Total & 76 & 100.0 & 100.0 & & \\
\hline \multicolumn{6}{|l|}{ Statistics } \\
\hline & & Gender & Age & Professional activity & \\
\hline$N$ & & 76 & 76 & 76 & \\
\hline Average & & 1.46 & 3.96 & 2.97 & \\
\hline Standard deviation & & 0.502 & 1.076 & 2.172 & Table 1. \\
\hline Variance & & 0.252 & 1.158 & 4.719 & Respondents' profile \\
\hline
\end{tabular}

Perceptions and attitudes toward higher education and reforms

Access to higher education has become, over the past two decades, highly democratized and accessible to a wide audience. This raises the question of its centrality and its value in the eyes of students and graduates, in particular, when we see that a large slice is doomed, at the end of its training, to unemployment and precariousness.

The Table 2 presents the survey population according to the degree prepared, there are a variety of the degrees prepared belonging to the two higher education regimes (Classic and LMD) and all levels (License, Master, Magister, Doctorate LMD and doctorate in science). We note through the crossover of the two variables (diploma and attitude) that the majority of respondents or 54 out of 76 respondents consider that there is a big difference between the two regimes, either in the teaching method or in the professional field. We find this attitude in all of the postgraduation respondents (Figure 1).

\begin{tabular}{lcrrr}
\hline \multicolumn{4}{c}{ Difference classic system and } & \\
Diploma prepared & Yes & LMD? & Total & \\
\hline License & 11 & 10 & 21 & \\
Master & 19 & 7 & 26 & \\
Magister & 3 & 0 & 11 & Table 2. \\
PhD Es & 11 & 0 & 15 & Attitude toward \\
PhD LMD & 10 & 5 & 76 & education systems \\
Total & 54 & 22 & & \\
\hline
\end{tabular}


HEED

14,2

100

Figure 1.

The attitude of graduates with regard to the content of training followed

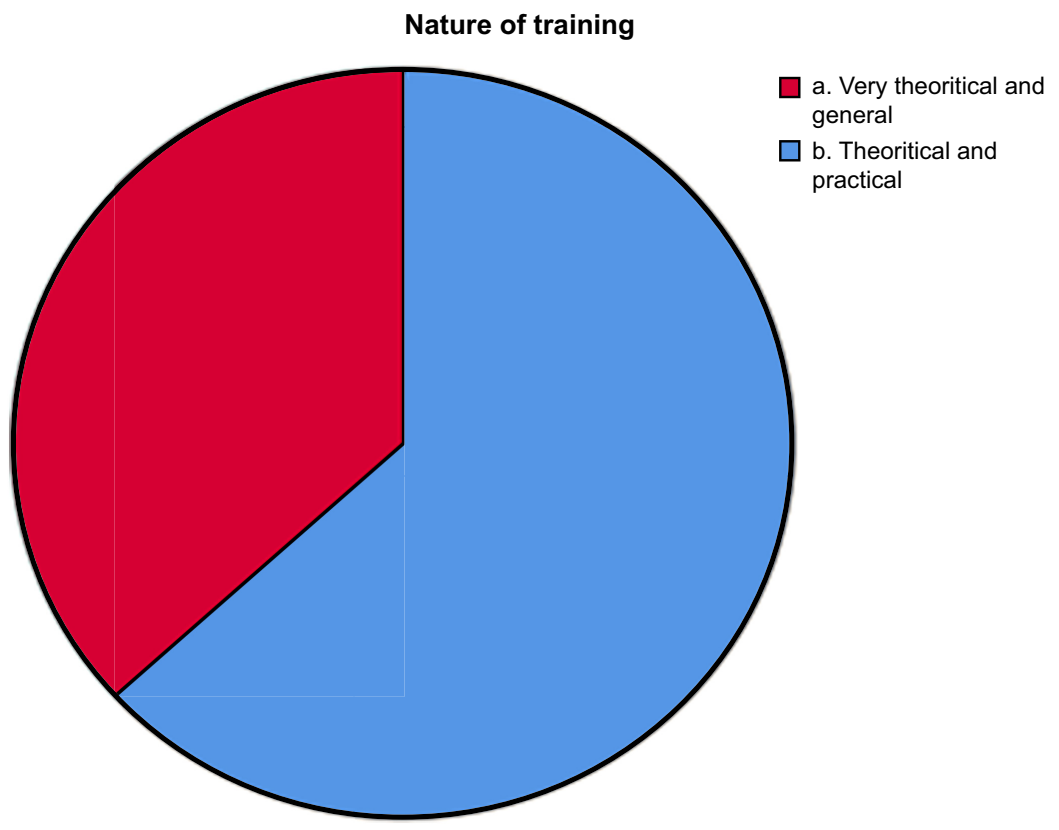

The diagram above presents the opinion of our respondents in relation to the content of the university training they followed. To this end, more than $64 \%$ of those questioned describe university training as very theoretical and general compared to $35.5 \%$ who rather consider it to be a mixture of theory and practice. This attitude toward training informs us about the professional future of graduates who also declare that there is no difference between the LMD and traditional system with regard to the adaptation of training to the job market. job.

In response to an open question on the representations that graduates of higher education make of the LMD system, the majority of those questioned describe it as liquidation given the duration and content of their training. In addition, several interviewees perceive this system as responsible for the phenomenon of unemployment of graduates because of the large flows that it forms each year without adapting to the needs and demand of the labor market. The higher education diploma therefore remains unsuitable with a very low employability rate, especially for mass streams such as human and social sciences and even literary. "I think the LMD system is less efficient than the classic one. Modules are biannual and in addition, what still causes the problem is the core curriculum. I admit that I did not have a good undergraduate training. However, I am satisfied by the master training. I was victim of a very short educational system; we received a lot of cluttered information in a short period of time, and sometimes teachers are not very competent. Besides, during the whole course of national education we used to receive everything from our teachers, unlike the LMD where the student must do the training and rely on himself", says one of our respondents.

The answers to these questions show that the Algerian state is far from winning the bet and the flow/quality equation seems difficult to solve. Basically, we can categorize the main results as follows:

The psychosociological and academic profile of young graduates which is characterized by a variety reflecting the initial structure of the mother population. A very large segmentation (in terms of the training followed and the job held) where 
several respondents emphasize this gap between the academic training and the professional career, an increasingly frequent problem given the large number of graduates who do not even manage to follow a practical internship at the end of the cycle which constitutes one of the rare opportunities for a student to see closely the functioning of the professional world.

In the private professional field, the master's degree is comparable to the traditional license. (An LMD license is not enough!). This shows a situation of inflation and downgrading of diplomas. Therefore, the problem of employability is always posed acutely.

\section{Conclusion}

The analysis of the system of representations and perceived perceptions shows that graduates of the two systems do not really rely on their training to learn everything from the professional world (too theoretical, general,) as the majority of our respondents said. "In all the Arab countries studied, a sort of vicious circle is established, in front of which the public authorities seem quite destitute: the increase in the number of pupils and students leads to a significant devaluation of diplomas, a process which leads to a tendency among these pupils and students to extend the duration of their studies in order to reach levels of study which they hope will protect them from unemployment" (Bashshur et al., 2006).

We think that higher education reforms are perceived differently by higher education actors, on the one hand, national and international officials have a very positive attitude toward them by highlighting the different advantages offered (international mobility, interchangeability of skills, unification of training, ...), and on the other hand, the restricted university family, in particular teachers and students who do not share this opinion and rather declare that the higher education system did not manage to produce the expected economic and social effects because it did not take into account the social, cultural and economic specificities of the Maghreb countries.

While the primary objective is to find the right formula for the adequacy between university training and job market, this is not achieved due to the increasing complexity of the university environment and the nature of the training judged very theoretical by our respondents.

Furthermore, the adaptation of university training to the needs of the labor market remains a problem which concerns not only the higher education system but also and above all the Algerian economic system which does not fully meet the standards of a true knowledge-based economy.

\section{Notes}

1. As its name suggests, this process was initiated in the city of Bologna in Italy in 1999 following the meeting of European ministers for a "Europe of knowledge" which aims to unify higher education systems.

2. For the European commission, The Bologna Process seeks to bring more coherence to higher education systems across Europe. It established the European Higher Education Area to facilitate student and staff mobility, to make higher education more inclusive and accessible, and to make higher education in Europe more attractive and competitive worldwide. As part of the European Higher Education Area, all participating countries agreed to: introduce a three-cycle higher education system consisting of bachelor's, master's and doctoral studies, ensure the mutual recognition of qualifications and learning periods abroad completed at other universities, and finally, implement a system of quality assurance, to strengthen the quality and relevance of learning and teaching.

3. By classical education system, we mean an annual organization of teaching units where the student follows a four-year training course to obtain the license diploma.
Massification and quality 
HEED

14,2

102

\section{References}

Ali-Rachedi and Abdesselam (2006), "La Voie De L'autonomie”, El Watan Alger.

Bashshur, M., Courbage, Y. and Labaki, B. (dir) (2006), L'enseignement Supérieur Dans le Monde Arabe, Une Question de Niveau, IFPO, Beyrouth, p. 214.

Buckner, E. (2019), "The role of higher education in the Arab state and society", Journal of Comparative and International Higher Education, Spring, Vol. 3, pp. 21-26.

Calderon, A. (2018), Massification of Higher Education Revisited, ReMIT, Melbourne.

Ferroukhi, J. (2009), "L’Algérie”, Algeria,éd, in, Labaki, B. (Ed.), Enseignement supérieur et Marché du Travail dans le Monde Arabe, Institut Français du Proche Orient, Paris.

Ghouati, A. (2012), "La dépossession-Réformes, enseignement supérieur et pouvoirs au Maghreb", Revue des Mondes Musulmans et de la Méditerranée, Vol. 131, pp. 65-90.

Guri-Rosenblit, S., Šebkova, H. and Teichler, U. (2007), "Massification and diversity of higher education systems: interplay of complex dimensions", Higher Education Policy, Vol. 20 No. 4, pp. 373-389.

Hatimi, I.E. (2018), "Internationalization and globalization, and their effect on higher education institutions in the Arab world", Higher Education Governance in the Arab World, Vol. 11.

Hely, M. and Oeser, A. (2015), "Économie(s) de la connaissance ? La valeur du savoir dans les sociétés néolibérales", Des États-Unis à l'Europe, Universités en régime néolibéral, Bulletin de l'ASES, Vol. 42, - Mars, Paris, association des sociologues enseignant(es) du supérieur, available at: $\mathrm{http}$ //sociologuesdusuperieur.org/index.php/article/introduction-economies-de-la-connaissancela-valeur-du-savoir-dans-les-societes (consulté le 25 Février 2020).

Khelfaoui, H. (2003), "Le champ universitaire algérien entre pouvoir politique et champ économique", Acte de Recherche en Sciences Sociales, Paris, Vol. 143 No. 3.

Knight, J. (2008), “The Internationalization of higher education in the 21st century: new realities and complexities", Higher Education in Turmoil, Brill Sense, pp. 1-18.

Law no. 08-04 of 15 Muharram 1429 corresponding to 23 January 2008 on the orientation law on national education (2008), Official Journal of the Algerian Republic $N^{\circ}$ 04, January.

Leclerc-Olive, M., Ghellab, G.S. and Wagner, A.-C. (2011), Les Mondes Universitaires Face au Marché, Circulation des Savoirs et Pratiques des Acteurs, KARTHALA, Paris.

Lynch, K. (2006), “Neo-liberalism and marketisation: the implications for higher education”, European Educational Research Journal, Vol. 5 No. 1, pp. 1-17.

Migaud, M. et al. (2019), "La mobilité internationale des étudiants, S’organiser pour les défis à venir", available at: www.ccomptes.fr.

Trow, M. (2006), "Reflections on the Transition from elite to mass to universal access: forms and phases of higher education in modern societies since WWII", in Forest, J.J.F. and Altbach, P.G. (Eds), International Handbook of Higher Education, Springer, Dordrecht, pp. $243-280$.

Wilkens, K. (2011), Higher Education Reform in the Arab World, Saban Center at Brookings.

Winston, C.T. (2016), "Educational theories and philosophies", Education and Society, Oxford research encyclopedia, Online Publication Date, Jul 2017, doi: 10.1093/acrefore/9780190264093. 013.49.

\section{Further reading}

Labaki, B. (2009), Enseignement Supérieur et Marché du Travail Dans le Monde Arabe, Presses de l'IFPO, Beyrouth.

Loi (2008), "Loi, n 08-04 du 15 Muharram 1429 correspondant au23 janvier 2008 portant loi d'orientation sur l'éducation nationale", Journal officiel de la République Algérienne 04 Janvier. 
Rapport de l'Unesco sur la science : vers 2030, available at: https://fr.unesco.org/Rapport_UNESCO_ science (Consulté le 12 Février 2020).

Rapport de l'Unesco, "Assurance qualité interne : améliorer la qualité et l'employabilité des diplômés du supérieur”, available at: https://unesdoc.unesco.org/ark:/48223/pf0000367775 (Consulté le 12 février 2020).

Regard sur l'éducation (2018), "Les indicateurs de l'OCDE", available at: https://www.oecd.org/fr/ education/regards-sur-education/ (Consulté le 12 février 2020).

Vatin, F. (2014), Le Travail, Activité Productive et Ordre Social, PUPO, Paris.

Massification and quality

\section{Corresponding author}

Rabah Noui can be contacted at: nouirabah2015@gmail.com

For instructions on how to order reprints of this article, please visit our website:

www.emeraldgrouppublishing.com/licensing/reprints.htm

Or contact us for further details: permissions@emeraldinsight.com 